\title{
Morphological and ecophysiological root and leaf traits in ectomycorrhizal, arbuscular-mycorrhizal and non-mycorrhizal Alnus incana seedlings
}

\author{
Jouni Kilpeläinen • Aitor Barbero-López • Bartosz Adamczyk • \\ Pedro J. Aphalo • Tarja Lehto
}

Received: 12 October 2018 / Accepted: 18 December 2018 / Published online: 10 January 2019

(C) The Author(s) 2019

\begin{abstract}
Background and aims The aim was to assess possible benefits or drawbacks of arbuscular-mycorrhizal (AM) and ectomycorrhizal (EM) colonisation compared to no mycorrhizas (NM) in seedlings of the same host species. Eight broadleaf species were tested for mycorrhiza formation. Grey alder (Alnus incana) and four fungal species were selected for further experiments.

Methods Grey alder seedlings were inoculated with AM fungi Rhizophagus intraradices and Glomus hoi or EM
\end{abstract}

Responsible Editor: Hans Lambers.

J. Kilpeläinen · A. Barbero-López · T. Lehto $(\bowtie)$

School of Forest Sciences, University of Eastern Finland,

P.O. Box 111, 80101 Joensuu, Finland

e-mail: tarja.lehto@uef.fi

B. Adamczyk

Department of Agriculture and Institute for Atmospheric and Earth System Research (INAR), University of Helsinki, Helsinki,

Finland

\section{P. J. Aphalo}

Department of Biosciences, University of Helsinki, Helsinki, Finland

Present Address:

J. Kilpeläinen

Natural Resources Institute Finland (Luke), Natural Resources,

Forest Management, Joensuu, Finland

Present Address:

B. Adamczyk

Luke, Bioeconomy and Environment, Helsinki, Finland fungi Paxillus involutus plus an ascomycete isolated from Alnus roots or mock-inoculated (NM).

Results EM formed in 70\% of root tips and AM in 30\% of root length. AM plants were smaller than EM and $\mathrm{NM}$, but their specific root length (SRL) and specific leaf area (SLA) were highest. Net photosynthesis, stomatal conductance and shoot water potential did not differ between treatments. Foliar Ca, K, Mg, Mn, N, P and $\mathrm{S}$ concentrations $\left(\mathrm{mg} \mathrm{g}^{-1}\right)$ were highest in $\mathrm{AM}$ plants. However, total foliar contents (mg per plant) were lowest in AM plants, except for P, K and $\mathrm{Zn}$.

Conclusions The larger SRL and SLA suggest more efficient resource usage in AM plants, even though these were smaller than EM and NM plants. Grey alder is proposed as a new model species for comparisons between mycorrhiza types in cold climates.

Keywords Grey alder · Mycorrhiza · Nutrients . Photosynthesis $\cdot$ Stomatal conductance $\cdot$ Tannins

\section{Introduction}

Most research on mycorrhizas has focused separately on one of the types of mycorrhizas at a time: ectomycorrhizas (EM), arbuscular (AM), ericoid and orchid mycorrhizas. However, there is increasing interest in jointly comparing these different mycorrhiza types in terms of their functions and responses to environmental factors. Such comparisons are necessary for understanding the geographical distribution patterns of vegetation and associated mycorrhizal fungi, both in relation 
to prevailing environmental conditions and for predicting changes in these distribution patterns in the face of global change and land-use alterations (Vargas et al. 2010; Soudzilovskaia et al. 2015).

Most plant species form only one type of mycorrhizas. However, some woody plants are able to form both arbuscular mycorrhizas (AM) and ectomycorrhizas (EM). These include Alnus, Betula, Casuarina, Eucalyptus, Populus, Quercus and Salix species (Harley and Harley 1987; Arveby and Granhall 1998; Thormann et al. 1999; Chen et al. 2000; Querejeta et al. 2009). These species are potentially useful as model plants for comparisons of the function of AM and EM, as they should allow studying the differences between AM and EM without the confounding effects from differences between host-plant species. In addition, an ideal test plant should form both types of mycorrhizas consistently under the same growing conditions.

Current understanding about the environmental factors that favour the formation of EM or AM in the same host species is mainly derived from correlations in observational studies along field environmental gradients (Lodge 1989; Gehring et al. 2006; Querejeta et al. 2009) and a few field experiments (Gehring et al. 2006; Saravesi et al. 2011). There are few experimental studies comparing seedlings of the same species with either EM or AM; however, pot and microcosm studies allow the use of controlled environments, eliminating most of the variability in environmental conditions and interacting organisms. This approach is necessary for studying specific physiological mechanisms and gene expression, providing information complementary to that obtained in field studies. Previously used test plants include Eucalyptus species (Jones et al. 1998, Chen et al. 2000) and Salix repens, a small shrub with a maritime distribution (van der Heijden 2001, van der Heijden and Kuyper 2001). For studying cold-climate phenomena such as the effects of intermittent freezing and thawing plus wintertime waterlogging, the host plant should tolerate low temperatures.

For the study of the effects of the mycorrhizal status on the stress tolerance of the host plants it is an asset if the mycorrhizal status does not strongly affect the growth, nutrition and physiology of the host under non-stress conditions (Lehto 1992; Lehto and Zwiazek 2011). Cultivating AM, EM and non-mycorrhizal (NM) plants in identical conditions and using the same host plant will help in identifying the intrinsic differences between mycorrhiza types. Non-mycorrhizal status may lead to more growth in some circumstances, in particular with high availability of soluble nutrients and restricted root and hyphal extension (e.g. Plassard et al. 2000; Korhonen et al. 2019). Mycorrhizal fungi use carbohydrates provided by their host plants, but it is argued that plants usually have a surplus of carbon (Corrêa et al. 2012). As the biomass of AM fungi (AMF) is smaller than that of EM fungi (EMF), the carbohydrate allocation to the fungi probably differs (Gehring et al. 2006; Saravesi et al. 2011), which may or may not lead to differences in photosynthesis because of a larger carbohydrate sink in EM. It has been shown that plants provide AM also with fatty acids (Luginbuehl et al. 2017), and these are energetically more costly per mass unit than sugars. The water transport properties of the mycorrhizal root types can vary because of differences in the pathway of water from the soil into the root xylem or because of physiological differences such as aquaporin function (Lehto and Zwiazek 2011).

Based on numerous studies on $\mathrm{P}$ and $\mathrm{N}$ uptake, mycorrhizas are often presumed to have a significant role in nutrient uptake in general. However, the information on the uptake of most other nutrients is limited, particularly considering the differences between EM and $\mathrm{AM}$, the different forms of nutrients and different environmental conditions. Concerning the biochemical composition of plants, tannins are one of the compound groups that form a relatively large proportion of plant biomass, up to $20 \%$. This may vary in response to differential fungal colonisation and also nutritional status (Adamczyk et al. 2017).

We tested the colonisation success on eight boreal tree species, each separately inoculated with EM and AM fungi. Based on the results, we selected grey alder (Alnus incana (L.) Moench) as a test species for further comparisons. The main aim of this study was to compare AM, EM and non-mycorrhizal (NM) grey alder seedlings in the same controlled conditions and in the absence of stressors in relation to their growth, morphology, nutritional status, tannins, carbon uptake and water relations at two harvests.

\section{Material and methods}

Screening mycorrhizal colonisation on different tree species

Acer platanoides L., Alnus glutinosa (L.) Gaertn., Alnus incana (L.) Moench, Betula pendula Roth, Betula 
pubescens Ehrh. and Sorbus aucuparia L. were grown from seeds and Salix caprea L. from cuttings that were surface sterilised with $\mathrm{H}_{2} \mathrm{O}_{2}$. Populus tremula L. clonal plants of four clones, two male and two female (Randriamanana et al. 2014), were grown at first from buds in sterile conditions on $1 / 2$ MS dishes (Murashige and Skoog 1962) and then transplanted to pots. A. platanoides seeds were collected in Arboretum Mustila, Elimäki, Finland 29.10.2003, A. glutinosa Mustila origin H09-14-530, A. incana seed orchard Loppi (Natural Resources Institute Finland (Luke)), Finland, 1980's, B. pendula seed orchard SV426, B. pubescens seed orchard SV382, S. aucuparia seeds University of Eastern Finland, Joensuu campus park, autumn 2014 and S. caprea cuttings in forest, Kaavi, Finland, autumn 2013.

Acer platanoides was grown in peat (Luonnonturve, Kekkilä, Finland) and perlite (PlantePerl, Nordisk Perlite, Denmark) mixed in 1:4 volumes. Perlite and quartz sand (grain size $0.1-0.6 \mathrm{~mm}$ ) mixed in 1:1 vol. or pure perlite was used for A. glutinosa, peat (moderately to well decomposed; H5-6 on von Post scale) and quartz sand mixed in 1:4 vol. or pure quartz sand for $A$. incana, $B$. pendula and $S$. caprea. The growing pots of $B$. pubescens included perlite or quartz sand and the pots of $P$. tremula peat (Luonnonturve) and vermiculite (REC Indovent, Sweden) mixed in 1:1 vol.

The cultivated strains of AM fungi were $C c=$ Claroideoglomus claroideum (V314, Luke Laukaa), $G h=$ Glomus hoi (BEG 48, Luke Laukaa), Fm= Funneliformis mosseae (V307, Luke Laukaa), $R i=$ Rhizophagus intraradices (Myko-Ymppi, Luke Laukaa). The EM fungi were Am = Amanita muscaria (Joensuu, Finland), H=Hebeloma sp. (Lund, Sweden), $L l=$ Laccaria laccata (H. Heinonen-Tanski), La = Lactarius aspideus (Liperi, Finland), Lea $=$ Leccinum aurantiacum (Joensuu, Finland), $\mathrm{Pi}=$ Paxillus involutus (Joensuu, Finland), EMF1 = EMF-359-1-3, EMF2 = EMF-359-2-1, EMF3 = EMF-359-2-4. All other EM fungi were isolated from identified sporocarps except EMF1-EMF3, which were isolated from A. incana roots (from experimental plants in Kilpeläinen et al. 2016). For the isolation, visually distinctive mycorrhizal short roots were severed under a stereo microscope, rinsed in $70 \%$ ethanol for one minute, rinsed in sterile water three times, and then grown on Hagem agar plates. The fungi were identified as an ectomycorrhizal ascomycete, courtesy of Dr. T. Helgason. All EM fungi were previously grown on Hagem agar plates for 3-4 weeks, then stored in a cold room $\left(+5^{\circ} \mathrm{C}\right)$ for 6 months, re-inoculated onto a host plant in sterile conditions and reisolated to Hagem agar plates.

Lactarius aspideus is compatible with Salix species, L. aurantiacum with Populus, and the unidentified species from A. incana roots with Alnus. All other fungi used are considered generalists, able to colonise many host species. A soil mix from meadow and forest sites from eastern Finland was applied as inoculum too (Kilpeläinen et al. 2016, 2017). The soil and perlite were mixed in 3:7 vol. for A. incana and B. pendula, and soil, peat (Luonnonturve) and vermiculite mixed in 4:7:7 vol. for $P$. tremula.

The plants were inoculated with either a single isolate or with soil inoculum, with no mock inoculum (details below) after roots started to branch. The growth period was 8-10 weeks in growth chamber conditions as described below. Root samples were stained, and mycorrhizas were observed for 5-12 plants per fungal species (see below).

Cultivation of Alnus incana seedlings and fungal inoculations

Alnus incana seedlings were grown under controlled conditions in a walk-in growth chamber. For this experiment, 120 seedlings in individual pots were randomly selected from a larger population. Seeds, collected in Loppi, Southern Finland, were sterilised in $\mathrm{H}_{2} \mathrm{O}_{2}$ using tea infusers (Kilpeläinen et al. 2016) and sown in $165 \mathrm{~cm}^{3}$ plastic pots (Ray Leach 'Cone-tainers', Stuewe \& Sons, Tangent, OR, USA) filled with acid washed perlite (day 1 of the experiment). Eight seeds were sown in each pot; pots were covered with clingfilm and kept in a walk-in growth chamber (Conviron GR77, Controlled Environments, Winnipeg, MB, Canada). For germination, the conditions were constant air relative humidity of $90 \%$ and constant air temperature of $22{ }^{\circ} \mathrm{C}$, with illumination only by fluorescent tubes (VHO $215 \mathrm{~W}$, Sylvania Cool White, Sylvania, USA), with $20 \mathrm{~h}$ light and $4 \mathrm{~h}$ dark. Photon irradiance was set at $80 \mu \mathrm{mol} \mathrm{m}{ }^{-2} \mathrm{~s}^{-1}$ PAR. The pots were watered every second day with $50 \mathrm{ml}$ of tap water. On day 12 the photon irradiance was increased to $200 \mu \mathrm{mol} \mathrm{m}{ }^{-2} \mathrm{~s}^{-1}$ PAR, from this day onwards from both the same fluorescent tubes plus incandescent bulbs $(60 \mathrm{~W}$, Oy Airam, Finland) and on day 18, photon irradiance was increased to $350 \mu \mathrm{mol} \mathrm{m} \mathrm{m}^{-2} \mathrm{~s}^{-1}$ PAR. After day 18, the same day/night timing was maintained, but day/night air conditions changed $22{ }^{\circ} \mathrm{C} / 17^{\circ} \mathrm{C}$ and a relative humidity of $70 / 80 \%$. 
Seedlings were allocated at random to the three inoculation treatments, EM, AM and NM and inoculated on day 21. Seedlings in EM treatment were inoculated with Paxillus involutus and the fungus EMF-359-2-1. The latter was isolated from a visually distinctive morphotype of ectomycorrhizas of $A$. incana in a previous experiment (Kilpeläinen et al. 2016). Both were grown on Hagem agar plates. Soil was carefully removed with a spatula to reveal roots; inocula were added in contact with roots and covered with the removed soil. EM inoculation was done by adding three fungal pieces of $5 \mathrm{~mm} \times 5 \mathrm{~mm}$ from the actively growing hyphal front on agar plates. Seedlings in AM treatment were inoculated with Rhizophagus intraradices, which is available as a commercial product Myko-Ymppi (Luke, Laukaa), and Glomus hoi (BEG 48, Luke, Laukaa). They were grown in the roots of host plants and the air-dried, homogenised growing substrate (sand, perlite plus peat), including the AM-colonised roots, was applied as an inoculum. For the AM inoculation, the two AM cultures were mixed in a volume ratio $1: 1$ and then $2 \mathrm{ml}$ of the mixture was added into each corresponding pot. To compensate for the nutrients added with the inocula, $2 \mathrm{ml}$ of autoclaved AM inoculum were added to pots with EM seedlings, three Hagem agar pieces of $5 \mathrm{~mm} \times$ $5 \mathrm{~mm}$ without fungus were added to the AM seedlings, and both mock inocula were added to NM seedlings. Unlike in field conditions, the seedlings were not infected by nitrogen-fixing Frankia bacteria. After inoculation, the plants were watered daily.

Fertilisation started on day 39, using a Kekkilä irrigation fertiliser $(16.6 \% \mathrm{~N}, 4.0 \% \mathrm{P}, 25.3 \% \mathrm{~K}, 0.03 \% \mathrm{~B}$, $0.014 \% \mathrm{Cu}, 0.18 \% \mathrm{Fe}, 0.10 \% \mathrm{Mn}, 0.001 \% \mathrm{Mo}, 0.023 \%$ $\mathrm{Zn}$ ) at a $\mathrm{N}$ concentration of $20 \mathrm{mg}^{-1}$ on five days per week. The pots were flushed with an excess of the fertiliser solution. On day 60 the fertiliser concentration was increased to $30 \mathrm{mg}^{-1}$ of N. Part of the AM plants showed incipient symptoms of magnesium $(\mathrm{Mg})$ deficiency and on day $66,12 \mathrm{mg}$ of $\mathrm{Mg}$ per litre of water was added to the mix of water and fertiliser of all plants in each mycorrhizal treatment as $\mathrm{Mg}\left(\mathrm{NO}_{3}\right)_{2} \cdot 6 \mathrm{H}_{2} \mathrm{O}$. On day 68 the Kekkilä irrigation fertiliser was substituted with nutrient solution keeping the concentration at the same $30 \mathrm{mg} \mathrm{l}^{-1}$ of $\mathrm{N}$ (Riddoch et al. 1991). The additional $\mathrm{Mg}$ was supplied to all plants until day 73. On day 81 , the concentration of the nutrient solution was increased to $50 \mathrm{mg}^{-1}$ of $\mathrm{N}$, with all other nutrients proportionally increased. On day 48 , one of the germinated plants was selected from each pot based on healthy appearance and growth, and the discarded plants were cut at the root collar.

Measurements and harvests

On days 81 (harvest 1) and 89-90 (harvest 2), 20 replicate plants for each mycorrhiza treatment were chosen at random, i.e. 60 plants per harvest, and in total 120 plants and pots. In harvest 1 , a subset of 12 plants was used for root morphology and root tannin analyses and the rest of the root systems were harvested for mycorrhiza observation (details below). In harvest 2, gas exchange and shoot water potential were measured. The roots of 12 plants per treatment were separated from the substrate and mycorrhiza colonisation and root dry mass were determined. Total leaf area and leaf and stem biomass were determined in all 20 plants per treatment and harvest. After this, leaf samples were pooled in order to have large enough samples for nutrient analyses (see below).

The gas exchange and water potential were measured in harvest 2 on two consecutive days - 10 seedlings per day, 20 in total - and completed within three hours after midday each day. Carbon dioxide and water vapour exchange was determined with the portable instrument LI-6400 using a broadleaf cuvette (Li-Cor, Lincoln, NE, USA) at $24^{\circ} \mathrm{C}$ air temperature, $300 \mu \mathrm{mol} \mathrm{m} \mathrm{m}^{-2}$ PAR from a blue-red LED source, ambient $\mathrm{CO}_{2}$ at $450 \mu \mathrm{mol} \mathrm{mol}{ }^{-1}$, air flow rate $500 \mu \mathrm{mol} \mathrm{s}^{-1}$ and water vapour pressure $2 \mathrm{kPa}$ corresponding to relative humidity $70 \%$, giving a leaf to air vapour pressure difference of 0.9 to $1.0 \mathrm{kPa}$. Stomatal conductance $\left(\mathrm{g}_{\mathrm{s}}\right)$, net photosynthesis $\mathrm{A}$ and intercellular $\mathrm{CO}_{2}$ concentration $\left(\mathrm{C}_{\mathrm{i}}\right)$ were computed by the LI-6400. After stabilization, three measurements were taken at intervals of $1 \mathrm{~min}$. In further computations, the set of values used was the one with the median stomatal conductance (of the three consecutive measurements) for each plant. After the gas exchange measurements, the shoots were cut at soil surface and the shoot water potential was measured with a pressure chamber Model 1000 (PMS Instruments, Albany, OR, USA).

Chlorophyll concentration was assessed from the topmost fully expanded leaf with a SPAD-502 (Konica Minolta Sensing Europe B.V.), calculating the mean of three measurements for each seedling. The calibration of the data from chlorophyll measurements was done by the equation chlorophyll concentration $\left(\mu \mathrm{mol} \mathrm{m} \mathrm{m}^{-2}\right)=$ $10^{\left(\mathrm{M}^{\wedge} 0.26721\right)}$, based on Markwell et al. (1995), but 
substituting their calibration constant, 0.265 , with that of the SPAD unit used, 0.26721 (Randriamanana et al. 2012).

The leaves were separated from stems and scanned with a flatbed scanner (Expression 1640XL, Epson) using the software Epson scan (version 2.95E). The total leaf area of each seedling was determined using ImageJ (version 1.50a) image editor (Wang 2017). The stems and leaves were weighed after drying to constant mass at $40{ }^{\circ} \mathrm{C}$. The pots with the perlite and root systems were stored in a freezer at $-20{ }^{\circ} \mathrm{C}$ until root separation.

Root morphology and mycorrhizal colonisation

Pots were thawed at $6-10^{\circ} \mathrm{C}$. Roots were separated with forceps in tap water. In harvest 1 , the complete root systems of 10 plants in EM and AM and 12 plants in NM treatments were scanned (Expression 1640 flatbed scanner, Epson). The total root length, number of tips and mean root diameter were determined using WinRHIZO Pro (2012b) (Regent Instruments, Quebec, Canada). After being scanned, the roots were dried at $40{ }^{\circ} \mathrm{C}$ and weighed. For tannin analysis, randomly selected pairs of root systems within treatments were pooled to get large enough samples and ground with a ball mill to yield five replicates.

In harvest 1, eight plants per treatment were reserved for microscopy to assess colonisation by EM and AM and check for possible contamination in NM. In harvest 1 , the microscopy observations were exploratory, only to confirm that mycorrhizas had started forming, and these data are not shown. In harvest 2, 12 plants per treatment were used for microscopy. Two subsamples were taken, from depth of $0.5 \mathrm{~cm}$ to $3.0 \mathrm{~cm}$ and depth of $4.0 \mathrm{~cm}$ to $6.5 \mathrm{~cm}$. Each subsample had at least 150 root tips and 100 intersections in a $1.27 \mathrm{~cm}$ gridline drawn in a $90 \mathrm{~mm} \times 15 \mathrm{~mm}$ petri dish (Giovannetti and Mosse 1980). In cases when the initial root subsamples were not big enough to fill this requirement, larger subsamples from a wider range of depths or even the whole root system below a depth of $0.5 \mathrm{~cm}$ was examined.

The root samples from the EM treatment were stained using Ponceau S stain (Daughtridge et al. 1986). The numbers of EM short roots with mantle and non-mycorrhizal short roots were counted under a stereo microscope as numbers of root tips. The root samples from the AM and NM treatments were cleared and thereafter stained with methyl blue. They were first kept in a $10 \%$ potassium hydroxide solution overnight at room temperature, then transferred to an alkaline hydrogen peroxide solution at room temperature, and $20 \mathrm{~min}$ later transferred to a $1 \%$ hydrochloride dilution for two hours at room temperature. The staining was done by immersion of the samples for one hour and a half in a pre-heated solution containing lactic acid, glycerol and methyl blue (Grace and Stribley 1991) at $80{ }^{\circ} \mathrm{C}$. Quantification of AM was done using the gridline intersect method under a stereo microscope (Giovannetti and Mosse 1980). Root intersections with the gridline were counted and the presence of hyphae, arbuscules, spores, vesicles or none at each one recorded. In cases when the presence of mycorrhiza was uncertain, roots were additionally observed under a light microscope at higher magnification.

The subsamples used for assessment of mycorrhizas together with the remaining parts of the root systems were dried at $40{ }^{\circ} \mathrm{C}$ for total root dry mass determination.

\section{Foliar nutrient analyses}

Leaf pooling within each mycorrhizal treatment and harvest was needed to obtain sufficiently large samples for nutrient analyses. From harvest 1, all leaves of 10 seedlings were combined in each pooled sample, thus two pooled samples were analysed for each mycorrhizal treatment. From harvest 2, all leaves of five seedlings were combined in each pooled sample, thus four pooled samples per mycorrhizal treatment were chemically analysed. Total nitrogen concentration was analysed using the Kjeldahl method (Halonen et al. 1983). For other nutrients MARS5 microwave wet digestion in $\mathrm{HNO}_{3}$ and $\mathrm{H}_{2} \mathrm{O}_{2}$ in Teflon containers (method based on Epa 3051 (U.S. EPA 2007)) was done and then ICPOES (Iris Intrepid II XSP, Thermo Elemental, Franklin, MA, USA) was used to measure elemental concentrations in the digests. Technical replicates were used to check the consistency of the results. Foliar nutrient contents per tree were calculated by multiplying the concentrations by the mean dry mass of leaves of the pooled trees ( $n=2$ in harvest 1 and $n=4$ in harvest 2).

\section{Total tannin concentration}

Root tannins were analysed from the same plants that were used in the root morphology measurement with WinRhizo. There were 10 plants per treatment (two were discarded at randomisation to get equal number of replicates). Randomly selected pairs of root systems 
within each mycorrhizal treatment were pooled and ground with a ball mill to yield five replicates. Concentration of tannins was measured using the protein precipitating method of Hagerman and Butler (1978) as described in Adamczyk et al. (2008). This method measures the total amount of tannins (both condensed and hydrolysable) precipitated by protein. Tannic acid (Sigma Chemicals), characterized in Adamczyk et al. (2012), was used as a standard. Samples were measured in 3 technical replicates and the mean of these was used in statistics and reporting. The results are presented as milligrams of tannic acid equivalents per gram of dry plant material.

\section{Statistical analysis}

The data were subjected to analysis of variance, using the mycorrhizal treatment as a fixed factor. For the measurements that were done in both harvests, a factorial ANOVA with factors mycorrhiza treatment $\times$ harvest was used. In case the mycorrhiza treatment was significant $(P \leq 0.05)$ or nearly significant $(0.05<P \leq$ 0.1 , Tukey's test was done for the main effect of mycorrhiza. If the interaction of harvest and mycorrhiza treatment was significant, the ANOVA and Tukey's test were repeated for each harvest separately. All data were analysed using the software IBM SPSS Statistics 21.

\section{Results}

Mycorrhizal colonisation in eight tree species

In the mycorrhizal colonisation tests with four species of AMF, nine isolates of EMF or soil inoculum, Acer and Sorbus formed only AM while both Betula species had only EM (Table 1). Both Alnus species formed both types but A. glutinosa had less AM colonisation. Salix caprea had more AM than EM. Populus tremula had EM although also some intraradical AM hyphae.

\section{Mycorrhiza colonisation in the Alnus incana experiment}

The colonisation rates of EM were between $50 \%$ and $80 \%$ of root tips (mean \pm SE $70.7 \pm 1.74 \%$ ). In the case of $\mathrm{AM}$, there was a high variability in the colonisation

Table 1 Mycorrhizal colonisation tests with different tree and fungal species ( $n=5-12$ per species combination)

\begin{tabular}{|c|c|c|c|c|c|c|c|c|c|}
\hline & $\begin{array}{l}\mathrm{AM} / \\
\mathrm{EM}\end{array}$ & $\begin{array}{l}\text { Acer } \\
\text { platanoides }\end{array}$ & $\begin{array}{l}\text { Alnus } \\
\text { glutinosa }\end{array}$ & $\begin{array}{l}\text { Alnus } \\
\text { incana }\end{array}$ & $\begin{array}{l}\text { Betula } \\
\text { pendula }\end{array}$ & $\begin{array}{l}\text { Betula } \\
\text { pubescens }\end{array}$ & $\begin{array}{l}\text { Populus } \\
\text { tremula }\end{array}$ & $\begin{array}{l}\text { Salix } \\
\text { caprea }\end{array}$ & $\begin{array}{l}\text { Sorbus } \\
\text { aucuparia }\end{array}$ \\
\hline$C c$ & $\mathrm{AM}$ & n.a. & + & ++ & - & n.a. & -1 & ++ & n.a. \\
\hline$G h$ & AM & +++ & + & ++ & - & - & -1 & ++ & + \\
\hline$F m$ & $\mathrm{AM}$ & n.a. & n.a. & + & - & n.a. & n.a. & ++ & n.a. \\
\hline$R i$ & $\mathrm{AM}$ & +++ & ++ & ++ & - & - & -1 & ++ & ++ \\
\hline$A m$ & EM & - & + & + & +++ & ++ & n.a. & n.a. & - \\
\hline$H$ & EM & - & + & + & +++ & ++ & - & n.a. & - \\
\hline$L l$ & EM & n.a. & n.a. & n.a. & n.a. & n.a. & + & n.a. & n.a. \\
\hline$L a$ & EM & n.a. & n.a. & n.a. & n.a. & n.a. & n.a. & + & n.a. \\
\hline Lea & EM & n.a. & n.a. & n.a. & n.a. & n.a. & + & n.a. & n.a. \\
\hline$P i$ & EM & - & ++ & + & +++ & ++ & - & + & - \\
\hline EMF1 & EM & n.a. & + & n.a. & n.a. & n.a. & n.a. & n.a. & n.a. \\
\hline EMF2 & EM & n.a. & + & n.a. & n.a. & n.a. & n.a. & n.a. & n.a. \\
\hline EMF3 & EM & n.a. & + & n.a. & n.a. & n.a. & n.a. & n.a. & n.a. \\
\hline Soil & $\mathrm{AM}$ & n.a. & + & $+++*$ & -* & n.a. & -1 & n.a. & n.a. \\
\hline Soil & EM & n.a. & + & $+++*$ & $+++*$ & n.a. & ++ & n.a. & n.a. \\
\hline
\end{tabular}

Fungal species: $C c=$ Claroideoglomus claroideum, $G$ h $=$ Glomus hoi, $F m=$ Funneliformis mosseae, Ri $=$ Rhizophagus intraradices, Am $=$ Amanita muscaria, $\mathrm{H}=$ Hebeloma, Ll = Laccaria laccata, La = Lactarius aspideus, Lea = Leccinum aurantiacum, $\mathrm{Pi}=$ Paxillus involutus, EMF1 = EMF-359-1-3 strain isolated from A. incana roots, EMF2 = EMF-359-2-1 strain isolated from A. incana roots, EMF3 = EMF-3592-4 strain isolated from $A$. incana roots, Soil AM = Soil from meadow and forest sites from eastern Finland leading to AM colonisation, Soil $\mathrm{EM}=$ Soil from meadow and forest sites leading to $\mathrm{EM}$ colonisation. $\mathrm{EM}=$ ectomycorrhizal, $\mathrm{AM}=$ arbuscular mycorrhizal, $\mathrm{EMF}=$ ectomycorrhizal fungi. Mycorrhizal colonisation: None (-), Limited ( $<10 \%$ of root length or root tips for AM and EM, respectively, + ), Moderate $(\geq 10 \%$ and $<30 \%,++)$, Abundant $(\geq 30 \%,+++)$, Not applied (n.a.)

* Kilpeläinen et al. 2016, 2017. ${ }^{1}$ Only AM hyphae found 
percentage per root length $(31.8 \pm 5.9 \%)$, with colonisation rates up to $65 \%$; in two seedlings no arbuscules were found (mean of arbuscules per root length $11.4 \pm$ $2.8 \%)$. Spores occurred on ca. $1 / 10$ of root length (10.2 $\pm 2.87 \%)$. Vesicles were found only in one seedling with a vesicle percentage of $0.53 \%$. No contamination of AM and EM was found in NM seedlings, or crosscontamination with the other mycorrhiza type in the inoculated seedlings. There was no air- or seed-borne Frankia colonisation either, as observed during microscopy.

Water potential, gas exchange and chlorophyll

There were no statistically significant differences in the shoot water potential, stomatal conductance, intercellular $\mathrm{CO}_{2}$ concentration, photosynthesis per leaf area and chlorophyll concentrations between the mycorrhizal treatments (Table 2). Photosynthesis per leaf dry mass was somewhat higher in AM than in the other treatments $\left(P_{\text {anova }}=0.054\right)$.

Root morphology and tannins

The number of root tips per plant was similar between treatments but the number of root tips per root length was significantly different between all the treatments, highest in AM and lowest in NM $\left(P_{\text {anova }}<0.001\right)$ (Table 3). The mean number of tips per root dry mass was largest in AM and root diameter was smallest in AM (Table 3). Total root length did not differ significantly between the

Table 2 Mean $( \pm \mathrm{SE})$ shoot water potential $(\Psi)$, stomatal conductance $\left(g_{s}\right)$, intercellular $\mathrm{CO}_{2}$ concentration $\left(\mathrm{C}_{\mathrm{i}}\right)$, photosynthesis per leaf area (A) and per leaf dry mass (A/DM) plus chlorophyll mycorrhizal treatments $\left(P_{\text {anova }}=0.140\right)($ Fig. 1a) but the specific root length $\left(P_{\text {anova }}=0.007\right)$ was highest in AM treatment (Fig. 1b). There were no significant differences in the root tannin concentrations (Table 3).

Plant dry mass and its allocation

The harvest effect was highly significant $\left(P_{\text {anova }}<\right.$ 0.001 ) for the dry mass of the plant parts and total, and the mycorrhiza effect was significant as well, but the interactions were not. Both the aboveground parts $\left(P_{\text {anova }} \leq 0.009\right)$ and the root dry mass $\left(P_{\text {anova }}=0.011\right)$ as well as the total plant dry mass $\left(P_{\text {anova }}<0.001\right)$ of the AM seedlings were smaller than EM and NM (Fig. 2). The mean total dry mass of AM plants was $73 \%$ of that of EM in harvest 1, and $82 \%$ in harvest 2. Leaf and root mass ratios did not differ significantly between the treatments. Between the harvests there was a significant shift in allocation from leaves towards roots but it was not affected by the mycorrhiza treatment (Table 4). The stem mass to total plant mass ratio was slightly smaller in AM. The total leaf area was smallest and the specific leaf area (SLA) was largest in AM at both harvests, with no difference between EM and NM (Table 4).

\section{Foliar nutrients}

Several nutrient concentrations as N, P, K, Ca, Mg, Mn and $\mathrm{S}$, were highest in the AM plants, while $\mathrm{B}$ and $\mathrm{Zn}$ did not show a significant mycorrhizal effect (Table 5). In harvest 2, the nutrient concentrations had decreased

concentration per leaf area $\left(\mathrm{Chl}_{\text {area }}\right)$ and leaf mass $\left(\mathrm{Chl}_{\text {mass }}\right)$ in harvest 2 by mycorrhizal treatments $(n=20)$

\begin{tabular}{lllll}
\hline Trait & EM & AM & NM & $P_{\text {anova }}$ \\
\hline$\Psi(\mathrm{MPa})$ & $-0.49(0.020)$ & $-0.47(0.023)$ & $-0.45(0.018)$ & 0.416 \\
$\mathrm{~g}_{\mathrm{s}}\left(\mathrm{mol} \mathrm{m} \mathrm{s}^{-1}\right)$ & $0.147(0.012)$ & $0.174(0.015)$ & $0.159(0.013)$ & 0.378 \\
$\left.\mathrm{C}_{\mathrm{i}}(\mu \mathrm{mol} \mathrm{mol})^{-1}\right)$ & $332(6.54)$ & $345(5.17)$ & $338(6.80)$ & 0.379 \\
$\mathrm{~A}\left(\mu \mathrm{mol} \mathrm{m} \mathrm{s} \mathrm{s}^{-1}\right)$ & $7.99(0.313)$ & $8.15(0.365)$ & $7.97(0.207)$ & 0.899 \\
$\mathrm{~A} / \mathrm{DM}\left(\mu \mathrm{mol} \mathrm{g}^{-1} \mathrm{~s}^{-1}\right)$ & $0.186(0.008)^{a b}$ & $0.213(0.012)^{b}$ & $0.184(0.0072)^{a}$ & 0.054 \\
$\mathrm{Chl}_{\text {area }}\left(\mu \mathrm{mol} \mathrm{m}^{-2}\right)$ & $330(10.3)$ & $306(10.2)$ & $322(10.9)$ & 0.243 \\
$\mathrm{Chl}_{\text {mass }}\left(\mu \mathrm{mol} \mathrm{g}^{-1}\right)$ & $7.71(0.270)$ & $7.88(0.210)$ & $7.39(0.260)$ & 0.368 \\
\hline
\end{tabular}

Gas exchange measured in the growth PAR

$P$ values from one-way ANOVA $\left(\mathrm{df}_{\text {error }}=57\right)$ are italicised if $0.05<P \leq 0.10$; different letters indicate differences between treatments (Tukey's test, $P \leq 0.05$ )

$E M$ ectomycorrhizal, $A M$ arbuscular mycorrhizal, $N M$ non-mycorrhizal 
Table 3 Means $( \pm$ SE) of morphological characteristics $(n=10$ for EM and 12 for AM and NM) and tannin concentrations $(n=5$, each sample pooled from two seedlings) of roots in harvest 1

\begin{tabular}{lllll}
\hline Trait & EM & AM & NM & $P$ \\
\hline Root tips per plant & $1163(69)$ & $1105(72)$ & $972(55)$ & 0.110 \\
Root tips $\left(\mathrm{mg}^{-1}\right)$ & $12.6(0.91)^{\mathrm{a}}$ & $17.4(1.01)^{\mathrm{b}}$ & $10.9(0.57)^{\mathrm{a}}$ & $<0.001$ \\
Root tips $\left(\mathrm{cm}^{-1}\right)$ & $2.52(0.103)^{\mathrm{b}}$ & $2.85(0.099)^{\mathrm{c}}$ & $2.22(0.070)^{\mathrm{a}}$ & $<\mathbf{0 . 0 0 1}$ \\
Mean diameter $(\mathrm{mm})$ & $0.436(0.014)^{\mathrm{b}}$ & $0.354(0.014)^{\mathrm{a}}$ & $0.456(0.012)^{\mathrm{b}}$ & $<\mathbf{0 . 0 0 1}$ \\
TAE $\left(\mathrm{mg} \mathrm{g}^{-1}\right)$ & $23.8(1.5)$ & $17.6(2.6)$ & $20.5(2.5)$ & 0.199 \\
\hline
\end{tabular}

$P$ values from one-way ANOVA $\left(\mathrm{df}_{\text {error }}=29\right.$ except for TAE $\left.\mathrm{df}_{\text {error }}=12\right)$ if $\leq 0.05$ are in bold; different letters indicate differences between treatments (Tukey's test, $P \leq 0.05$ )

$T A E$ tannic acid equivalents, $E M$ ectomycorrhizal, $A M$ arbuscular mycorrhizal, $N M$ non-mycorrhizal

with the growth of the plants, except for B, Ca and $\mathrm{Mn}$ that increased. Copper concentration was largest in EM and smallest in NM. The very large difference between harvests led to a nearly significant interaction for $\mathrm{Cu}$, but the difference between mycorrhizal treatments remained the same in the two harvests. Otherwise the interactions were not even near significant level.

In contrast to the foliar concentrations, the $\mathrm{N}$ and $\mathrm{Mg}$ and $\mathrm{S}$ contents were significantly lower in AM than NM and EM, which did not differ from each other (Table 6). For Ca this same effect was nearly significant (overall mean of AM smaller than EM and NM). In the cases of $\mathrm{P}, \mathrm{K}$ and $\mathrm{Zn}$ contents, the mycorrhizal effect was not significant (Table 6). The AM seedlings had lower B and $\mathrm{Mn}$ contents only in harvest 2 (nearly significant interaction). All the foliar nutrient contents increased with the growth of the plants (significant harvest effect). The differences between the mycorrhizal treatments became larger in harvest 2 , but the direction of effects was in general consistent between the harvests (most interactions far from significance).

\section{Discussion}

We aimed to identify one or more boreal tree species that would be useful for comparisons of AM and EM in young plants, and then do a comparison of different traits in the most promising species in non-stressing conditions. Out of the eight deciduous species tested, Acer platanoides and Sorbus aucuparia formed only $\mathrm{AM}$ and Betula pendula, B. pubescens and Populus

\section{a}

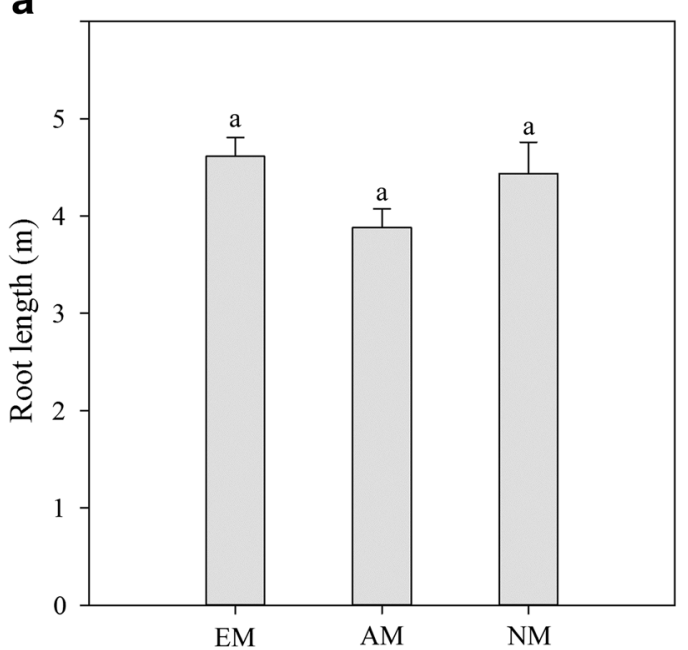

b

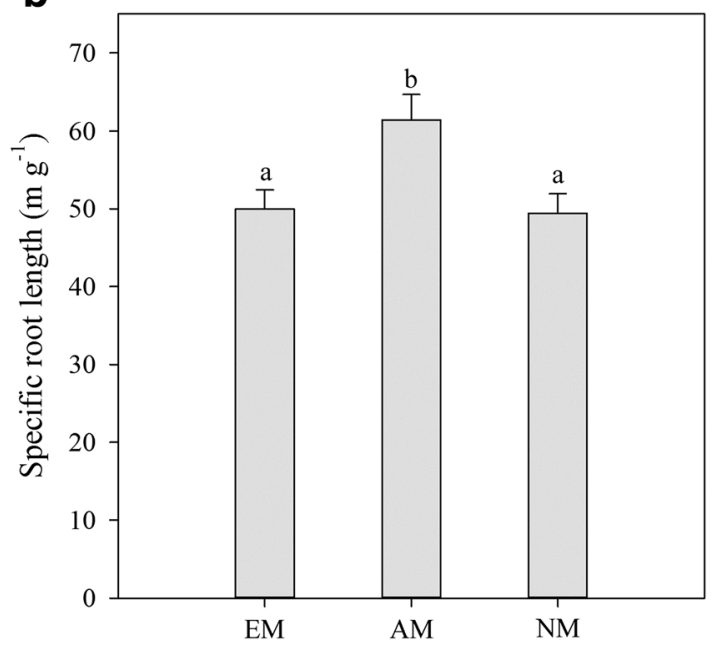

Fig. 1 Mean $( \pm \mathrm{SE})\left(\right.$ a) total root length $\left(P=0.140, \mathrm{df}_{\text {error }}=29\right)$ and $(\mathbf{b})$ specific root length $\left(P=0.051, \mathrm{df}_{\text {error }}=29\right)$ in harvest $1(n=10$ for $\mathrm{EM}$ and 12 for AM and NM). Different letters indicate differences between treatments (Tukey's test, $P \leq 0.05$ ) 
Fig. 2 Mean $( \pm$ SE) plant dry masses in different mycorrhizal treatments: $\mathrm{EM}=$ ectomycorrhizal, $\mathrm{AM}=$ arbuscular mycorrhizal, NM= non-mycorrhizal. For stem and leaf dry mass $n=20$ at each harvest and for roots $n=12$ at each harvest. Different lower-case letters indicate significant differences between treatments in dry masses of leaves, stems and roots and capital letters in total plant dry mass, both harvests tested together (Tukey's test, $P \leq$ $0.05)$

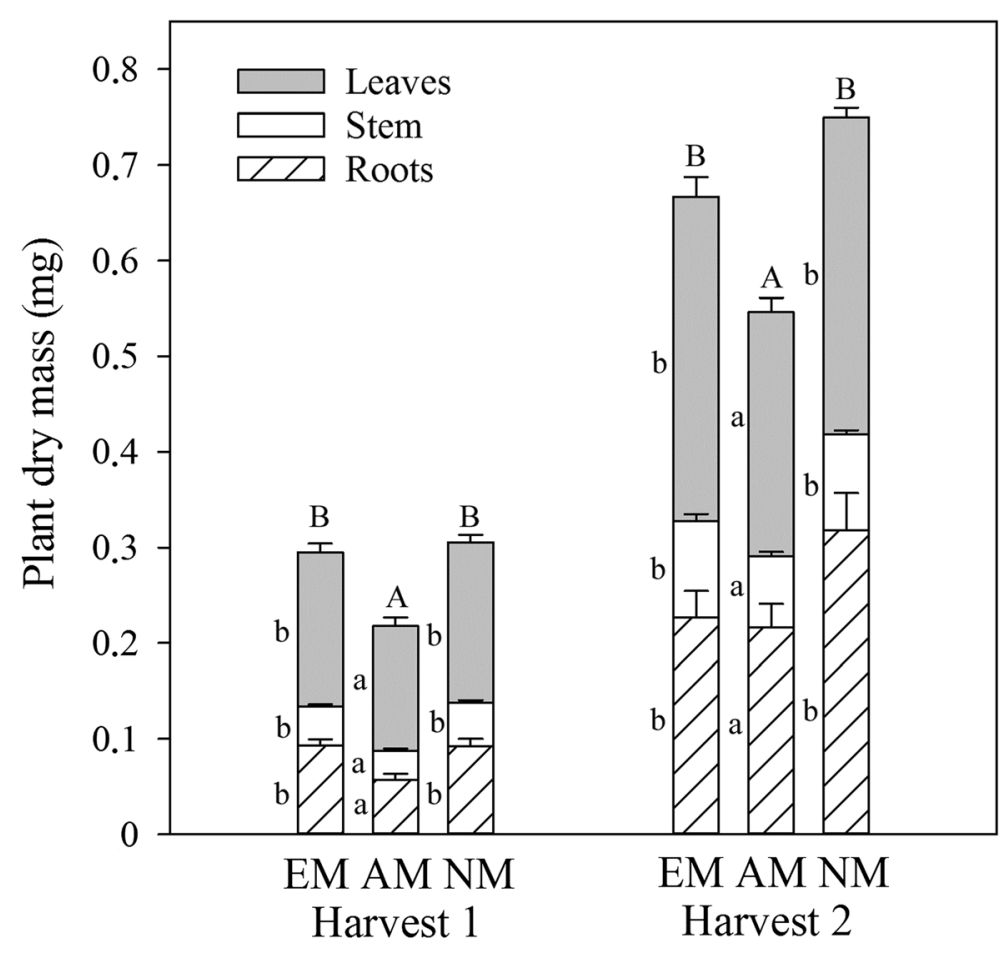

tremula only EM, although some AM hyphae were seen in the $P$. tremula roots. Only Alnus glutinosa, A. incana and Salix caprea formed both AM and EM. As $S$. caprea was more prone to AM than EM formation and A. glutinosa had few AM, A. incana, grey alder, was found to be the most promising species for further study.

Similarly, in previous studies, many hosts that formed both types of mycorrhizas showed a preference

Table 4 Mean ( \pm SE) dry mass ratios of leaves, stem and roots $(\%)$ of seedlings in harvests 1 and 2, $n=12$

\begin{tabular}{|c|c|c|c|c|c|c|c|}
\hline \multirow[t]{2}{*}{ Trait } & \multirow[t]{2}{*}{$\mathrm{H}$} & \multirow[t]{2}{*}{ EM } & \multirow[t]{2}{*}{$\mathrm{AM}$} & \multirow[t]{2}{*}{ NM } & \multicolumn{3}{|l|}{$P_{\text {anova }}$} \\
\hline & & & & & $M$ & $H$ & $M x H$ \\
\hline \multicolumn{8}{|c|}{ Dry mass ratios $(\%)$} \\
\hline \multirow[t]{2}{*}{ Stem:Total } & 1 & $14.3(0.48)$ & $13.8(0.61)$ & $15.5(0.58)$ & 0.083 & 0.694 & 0.388 \\
\hline & 2 & $14.9(0.69)$ & $14.0(0.54)$ & $13.7(0.67)$ & & & \\
\hline \multirow[t]{2}{*}{ Leaf:Total } & 1 & $56.0(0.43)$ & $60.4(2.14)$ & $55.1(0.74)$ & 0.415 & 0.007 & 0.433 \\
\hline & 2 & $51.4(1.48)$ & $46.6(1.33)$ & $45.5(1.84)$ & & & \\
\hline \multirow[t]{2}{*}{ Root:Total } & 1 & $29.7(0.73)$ & $25.7(1.81)$ & $29.3(0.85)$ & 0.272 & 0.038 & 0.486 \\
\hline & 2 & $33.7(1.82)$ & $39.4(1.38)$ & $40.7(2.42)$ & & & \\
\hline \multirow[t]{2}{*}{ Leaf area $\left(\mathrm{cm}^{2}\right)$} & 1 & $39.6(1.90)^{\mathrm{b}}$ & $35.3(2.43)^{\mathrm{a}}$ & $41.9(2.10)^{\mathrm{b}}$ & 0.015 & $<0.001$ & 0.469 \\
\hline & 2 & $79.0(4.77)$ & $65.6(3.64)$ & $75.9(2.41)$ & & & \\
\hline \multirow[t]{2}{*}{ SLA $\left(\mathrm{cm}^{2} \mathrm{~g}^{-1}\right)$} & 1 & $251(6.89)^{\mathrm{a}}$ & $273(6.37)^{\mathrm{b}}$ & $251(6.06)^{\mathrm{a}}$ & $<0.001$ & 0.171 & 0.365 \\
\hline & 2 & $234(5.01)$ & $260(6.54)$ & $230(5.37)$ & & & \\
\hline
\end{tabular}

Total leaf area per plant and specific leaf area (SLA), $n=20$. $P$ values from two-way ANOVA $\left(\mathrm{df}_{\text {error }}=64\right.$ or $\left.\mathrm{df}_{\text {error }}=114\right)$ if $\leq 0.05$ are in bold and italicised if $0.05<P \leq 0.10$. Different letters indicate differences between treatments (Tukey's test, $P \leq 0.05$ ); if the interaction is not significant, the mycorrhizal main effect is marked only in the line of harvest 1

$H$ harvest, $M$ mycorrhizal treatment, $M x H$ interaction, $E M$ ectomycorrhizal, $A M$ arbuscular mycorrhizal, $N M$ non-mycorrhizal 
Table 5 Mean $( \pm$ SE) foliar nutrient concentrations of the seedlings from different mycorrhizal treatments $(n=2$ in harvest 1 and $n=4$ in harvest 2)

\begin{tabular}{|c|c|c|c|c|c|c|c|}
\hline Nutrient & $\mathrm{H}$ & EM & $\mathrm{AM}$ & NM & $M$ & $H$ & $M x H$ \\
\hline $\mathrm{N}\left(\mathrm{mg} \mathrm{g}^{-1}\right)$ & $\begin{array}{l}1 \\
2\end{array}$ & $\begin{array}{l}24.8(0.262)^{\mathrm{ab}} \\
17.6(0.268)\end{array}$ & $\begin{array}{l}25.7(0.932)^{\mathrm{b}} \\
19.6(0.736)\end{array}$ & $\begin{array}{l}23.1(1.886)^{\mathrm{a}} \\
17.3(0.552)\end{array}$ & 0.030 & $<0.001$ & 0.661 \\
\hline $\mathrm{P}\left(\mathrm{mg} \mathrm{g}^{-1}\right)$ & $\begin{array}{l}1 \\
2\end{array}$ & $\begin{array}{l}2.36(0.002)^{\mathrm{a}} \\
1.63(0.050)\end{array}$ & $\begin{array}{l}2.53(0.020)^{\mathrm{b}} \\
2.07(0.053)\end{array}$ & $\begin{array}{l}2.21(0.187)^{\mathrm{a}} \\
1.56(0.065)\end{array}$ & $<0.001$ & $<0.001$ & 0.235 \\
\hline $\mathrm{K}\left(\mathrm{mg} \mathrm{g}^{-1}\right)$ & $\begin{array}{l}1 \\
2\end{array}$ & $\begin{array}{l}11.8(0.386)^{\mathrm{a}} \\
9.71(0.212)\end{array}$ & $\begin{array}{l}13.7(0.180)^{\mathrm{b}} \\
11.7(0.357)\end{array}$ & $\begin{array}{l}11.3(0.340)^{\mathrm{a}} \\
9.07(0.344)\end{array}$ & $<0.001$ & $<0.001$ & 0.952 \\
\hline $\mathrm{B}\left(\mu \mathrm{g} \mathrm{g}^{-1}\right)$ & $\begin{array}{l}1 \\
2\end{array}$ & $\begin{array}{l}14.1(0.520) \\
24.8(0.917)\end{array}$ & $\begin{array}{l}17.0(0.438) \\
26.6(0.387)\end{array}$ & $\begin{array}{l}17.2(2.30) \\
23.5(1.03)\end{array}$ & 0.118 & $<0.001$ & 0.137 \\
\hline $\mathrm{Ca}\left(\mathrm{mg} \mathrm{g}^{-1}\right)$ & $\begin{array}{l}1 \\
2\end{array}$ & $\begin{array}{l}3.90(0.275)^{\mathrm{a}} \\
4.88(0.163)\end{array}$ & $\begin{array}{l}5.01(0.579)^{\mathrm{b}} \\
5.62(0.133)\end{array}$ & $\begin{array}{l}4.49(0.341)^{\mathrm{a}} \\
4.95(0.148)\end{array}$ & 0.007 & 0.005 & 0.552 \\
\hline $\mathrm{Cu}\left(\mu \mathrm{g} \mathrm{g}^{-1}\right)$ & $\begin{array}{l}1 \\
2\end{array}$ & $\begin{array}{l}7.25(0.108)^{\mathrm{b}} \\
3.99(0.196)\end{array}$ & $\begin{array}{l}5.96(1.06)^{\mathrm{ab}} \\
3.89(0.111)\end{array}$ & $\begin{array}{l}5.45(0.225)^{\mathrm{a}} \\
3.76(0.221)\end{array}$ & 0.029 & $<0.001$ & 0.088 \\
\hline $\operatorname{Mg}\left(\mathrm{mg} \mathrm{g}^{-1}\right)$ & $\begin{array}{l}1 \\
2\end{array}$ & $\begin{array}{l}2.52(0.158)^{\mathrm{a}} \\
2.05(0.056)\end{array}$ & $\begin{array}{l}2.88(0.088)^{\mathrm{b}} \\
2.38(0.078)\end{array}$ & $\begin{array}{l}2.56(0.047)^{\mathrm{a}} \\
2.07(0.051)\end{array}$ & 0.002 & $<0.001$ & 0.993 \\
\hline $\operatorname{Mn}\left(\mu \mathrm{g} \mathrm{g}^{-1}\right)$ & $\begin{array}{l}1 \\
2\end{array}$ & $\begin{array}{l}54.7(1.64)^{\mathrm{a}} \\
72.6(1.82)\end{array}$ & $\begin{array}{l}63.4(1.01)^{b} \\
83.4(1.28)\end{array}$ & $\begin{array}{l}53.5(2.89)^{\mathrm{a}} \\
73.9(1.58)\end{array}$ & $<0.001$ & $<0.001$ & 0.773 \\
\hline $\mathrm{S}\left(\mathrm{mg} \mathrm{g}^{-1}\right)$ & $\begin{array}{l}1 \\
2\end{array}$ & $\begin{array}{l}1.43(0.012)^{\mathrm{a}} \\
0.907(0.013)\end{array}$ & $\begin{array}{l}1.60(0.058)^{\mathrm{b}} \\
1.08(0.028)\end{array}$ & $\begin{array}{l}1.36(0.076)^{\mathrm{a}} \\
0.869(0.029)\end{array}$ & $<0.001$ & $<0.001$ & 0.875 \\
\hline $\mathrm{Zn}\left(\mu \mathrm{g} \mathrm{g}^{-1}\right)$ & $\begin{array}{l}1 \\
2\end{array}$ & $\begin{array}{l}15.0(1.10) \\
9.04(0.608)\end{array}$ & $\begin{array}{l}12.0(1.07) \\
11.6(0.952)\end{array}$ & $\begin{array}{l}12.5(0.420) \\
10.6(1.76)\end{array}$ & 0.952 & 0.028 & 0.145 \\
\hline
\end{tabular}

$P$ values from two-way ANOVA $\left(\mathrm{df}_{\text {error }}=12\right)$ if $\leq 0.05$ are in bold and italicised if $0.05<P \leq 0.10$; different letters indicate differences between treatments (Tukey's test, $P \leq 0.05$ ), italicised if $0.05<P \leq 0.10$. As the interactions were not significant, the overall mycorrhizal main effect is shown (for $\mathrm{Cu}$, see text)

$H$ harvest, $M$ mycorrhizal treatment, $M x H$ interaction, $E M$ ectomycorrhizal, $A M$ arbuscular mycorrhizal, $N M$ non-mycorrhizal

to either type in given environmental conditions despite the often-reported dual-mycorrhizal symbioses (van der Heijden and Vosatka 1999; Chen et al. 2000; Saravesi et al. 2011). Single-type symbioses are generally more common in nature (Moora 2014). Perhaps the array of morphological and physiological modifications by the host is so different for the two mycorrhiza types that these are not often found together. In addition to the identity of the host and the fungus, the soil properties have an influence on the colonisation and efficacy of mycorrhizal associations (e.g. Johnson et al. 2010), and probably climatic factors affect as well (Kilpeläinen et al. 2016). Here in the colonisation experiments, we aimed to create conditions that would not favour one mycorrhiza type over the other.

The mycorrhizal inoculation in grey alder was successful, leading to $30 \%$ of the root length colonised in AM inoculated plants and $70 \%$ of mycorrhizal root tips in EM plants (harvest 2). These rates are similar as in grey alder grown in soils containing both AM and EM propagules (Kilpeläinen et al. 2017), while in another experiment we observed $40-50 \%$ of EM root tips and $40-50 \%$ root length colonised by AM in grey alder (Kilpeläinen et al. 2016). However, in those previous field-soil experiments, where there were both types of mycorrhizas in the same seedlings, there were fewer arbuscules than here. Our results contrast to field studies on grey alder in Sweden, where only AM were found in first-year seedlings and EM appeared in the second year (Arveby and Granhall 1998). A similar succession of AM followed by EM was shown in Quercus agrifolia (Egerton-Warburton and Allen 2001).

Here, AM plants were smaller than either EM or NM. Although the mass of the root systems in harvest 1 was smallest in AM, root length and especially the number of root tips were not much smaller. This resulted in more root tips per unit root length or mass in AM plants. A high degree of root branching is probably related to high nutrient uptake activity, and it was found to be the trait most dynamic and most affected by the environment out of 14 root traits analysed in temperate forest trees (Liese et al. 2017). Usually more root branching has been found 
Table 6 Mean $( \pm$ SE) foliar nutrient contents per plant in the seedlings of different mycorrhizal treatments $(n=2$ in harvest 1 and $n=4$ in harvest 2)

\begin{tabular}{|c|c|c|c|c|c|c|c|}
\hline Nutrient & $\mathrm{H}$ & EM & $\mathrm{AM}$ & NM & $M$ & $H$ & $M x H$ \\
\hline $\mathrm{N}(\mathrm{mg})$ & $\begin{array}{l}1 \\
2\end{array}$ & $\begin{array}{l}4.00(0.042)^{\mathrm{b}} \\
5.98(0.091)\end{array}$ & $\begin{array}{l}3.35(0.121)^{\mathrm{a}} \\
4.99(0.188)\end{array}$ & $\begin{array}{l}3.86(0.316)^{b} \\
5.73(0.183)\end{array}$ & 0.003 & $<0.001$ & 0.670 \\
\hline $\mathrm{P}(\mathrm{mg})$ & $\begin{array}{l}1 \\
2\end{array}$ & $\begin{array}{l}0.380(0.000) \\
0.554(0.017)\end{array}$ & $\begin{array}{l}0.329(0.003) \\
0.528(0.013)\end{array}$ & $\begin{array}{l}0.370(0.031) \\
0.517(0.022)\end{array}$ & 0.205 & $<0.001$ & 0.470 \\
\hline $\mathrm{K}(\mathrm{mg})$ & $\begin{array}{l}1 \\
2\end{array}$ & $\begin{array}{l}1.90(0.062) \\
3.29(0.072)\end{array}$ & $\begin{array}{l}1.79(0.023) \\
2.99(0.091)\end{array}$ & $\begin{array}{l}1.89(0.057) \\
3.00(0.114)\end{array}$ & 0.157 & $<0.001$ & 0.411 \\
\hline B $(\mu \mathrm{g})$ & $\begin{array}{l}1 \\
2\end{array}$ & $\begin{array}{l}2.27(0.084)^{\mathrm{a}} \\
8.40(0.311)^{\mathrm{c}}\end{array}$ & $\begin{array}{l}2.22(0.057)^{\mathrm{a}} \\
6.79(0.099)^{\mathrm{b}}\end{array}$ & $\begin{array}{l}2.88(0.384)^{\mathrm{a}} \\
7.77(0.340)^{\mathrm{c}}\end{array}$ & 0.028 & $<0.001$ & 0.060 \\
\hline $\mathrm{Ca}(\mathrm{mg})$ & $\begin{array}{l}1 \\
2\end{array}$ & $\begin{array}{l}0.629(0.044)^{b} \\
1.65(0.055)\end{array}$ & $\begin{array}{l}0.653(0.076)^{\mathrm{a}} \\
1.43(0.034)\end{array}$ & $\begin{array}{l}0.752(0.057)^{\mathrm{b}} \\
1.64(0.049)\end{array}$ & 0.054 & 0.001 & 0.133 \\
\hline $\mathrm{Cu}(\mu \mathrm{g})$ & $\begin{array}{l}1 \\
2\end{array}$ & $\begin{array}{l}1.17(0.017)^{\mathrm{b}} \\
1.35(0.066)\end{array}$ & $\begin{array}{l}0.777(0.139)^{\mathrm{a}} \\
0.993(0.028)\end{array}$ & $\begin{array}{l}0.913(0.038)^{\mathrm{a}} \\
1.25(0.073)\end{array}$ & 0.001 & 0.051 & 0.580 \\
\hline $\mathrm{Mg}(\mathrm{mg})$ & $\begin{array}{l}1 \\
2\end{array}$ & $\begin{array}{l}0.407(0.025)^{\mathrm{b}} \\
0.693(0.019)\end{array}$ & $\begin{array}{l}0.375(0.011)^{\mathrm{a}} \\
0.607(0.020)\end{array}$ & $\begin{array}{l}0.429(0.008)^{b} \\
0.685(0.017)\end{array}$ & 0.016 & $<0.001$ & 0.457 \\
\hline $\mathrm{Mn}(\mu \mathrm{g})$ & $\begin{array}{l}1 \\
2\end{array}$ & $\begin{array}{l}8.81(0.264)^{\mathrm{a}} \\
24.6(0.618)^{\mathrm{c}}\end{array}$ & $\begin{array}{l}8.26(0.131)^{\mathrm{a}} \\
21.3(0.327)^{\mathrm{b}}\end{array}$ & $\begin{array}{l}8.95(0.483)^{\mathrm{a}} \\
24.5(0.524)^{\mathrm{c}}\end{array}$ & 0.006 & $<0.001$ & 0.052 \\
\hline $\mathrm{S}(\mathrm{mg})$ & $\begin{array}{l}1 \\
2\end{array}$ & $\begin{array}{l}0.230(0.002)^{\mathrm{b}} \\
0.307(0.004)\end{array}$ & $\begin{array}{l}0.209(0.008)^{\mathrm{a}} \\
0.275(0.007)\end{array}$ & $\begin{array}{l}0.228(0.013)^{\mathrm{ab}} \\
0.288(0.010)\end{array}$ & 0.027 & $<0.001$ & 0.617 \\
\hline $\mathrm{Zn}(\mu \mathrm{g})$ & $\begin{array}{l}1 \\
2\end{array}$ & $\begin{array}{l}2.41(0.177) \\
3.06(0.206)\end{array}$ & $\begin{array}{l}1.56(0.139) \\
2.97(0.243)\end{array}$ & $\begin{array}{l}2.10(0.070) \\
3.52(0.584)\end{array}$ & 0.386 & 0.005 & 0.581 \\
\hline
\end{tabular}

$P$ values from two-way ANOVA $\left(\mathrm{df}_{\text {error }}=12\right)$ if $\leq 0.05$ are in bold and italicised if $0.05<P \leq 0.10$; different letters indicate differences between treatments (Tukey's test, $P \leq 0.05$ ), italicised if $0.05<P \leq 0.10$. When $P>0.10$ for the interaction term, the mycorrhizal main effect is shown only in harvest 1 . In the case of B and Mn, harvests 1 and 2 were tested separately $\left(P_{\text {interaction }}<0.10\right)$

$H$ harvest, $M$ mycorrhizal treatment, $M x H$ interaction, $E M$ ectomycorrhizal, $A M$ arbuscular mycorrhizal, $N M$ non-mycorrhizal

in EM tree species than AM, but one of the reasons for this is the formation of coralloid EM with very large numbers of tips close to each other (Liese et al. 2017).

$\mathrm{AM}$ roots were clearly thinner than in the other treatments, which led to somewhat higher specific root length (SRL). SRL is considered as an index of benefit to cost ratio, a high value describing a large absorbing surface area relative to the carbon cost of roots (Ostonen et al. 2007). During EM formation, root length growth ceases soon after root-tip infection, and mantle formation itself adds to the thickness of the mycorrhizal part of the root systems. Therefore, a larger SRL is to be expected in AM plants than in EM ones as a result of thinner AM roots, as found in eucalypt seedlings (Chen et al. 2000). On one hand, SRL has been found to change in response to many environmental factors and it has been described as a useful stress indicator (Ostonen et al. 2007). On the other hand, SRL does not include the surface area or the carbon cost of external mycelium, making its use for the comparison between different mycorrhizal roots somewhat problematic. This is so, because the extension and nutrient uptake capacity of the external mycelium vary greatly among fungal species within and between mycorrhiza types and can be functionally more important than that of the roots themselves. Moreover, in a between-species comparison, both AM and EM trees had an equal range of fine-root diameters, although SRL was not determined (Chen et al. 2016).

In comparisons between tree species, specific leaf area (SLA) and SRL are often positively correlated (Withington et al. 2006; Liese et al. 2017), and here we have shown the same pattern in AM and EM plants within a single host tree species. Similarly as SRL, SLA indicates larger surface area compared to biomass. Therefore, these morphological traits are associated with higher efficiency of resource use in structures and they should lead to higher nutrient and carbon assimilation per unit biomass. In a comparison of 15 silver birch (Betula pendula) genotypes, SLA was identified as the trait that correlated most with growth (alongside with fresh mass / dry mass ratio) out of 13 aboveground 
morphological and physiological traits (Possen et al. 2014). The traits assessed by Possen et al. (2014) included gas exchange and leaf water potential. Also, in the present study, gas exchange per unit leaf area and shoot water potential in non-stress conditions were not different in the mycorrhiza treatments. Similar $C_{i}$ and chlorophyll concentration indicate that there were no major differences in the photosynthetic apparatus. However, the $15 \%$ higher photosynthetic rate per unit leaf mass, following from higher SLA in AM plants yet suggests a more efficient use of resources in structures.

Shoot water potential and stomatal conductance taken together with the soil moisture level form a proxy for the hydraulic conductance of the soil-(fungus)-plantatmosphere continuum (Kramer and Boyer 1995). Here, soil moisture was not different in the mycorrhizal treatments, as the plants were watered frequently. Consequently, as no differences in stomatal conductance or plant water status could be detected, it is likely that hydraulic conductance of the soil-(fungus)-plant-atmosphere continuum was little affected by the treatments. Augé et al. (2015) reported that AM tended to increase stomatal conductance especially during drought conditions. The results on water relations of EM plants in comparison to NM plants have varied between different studies, showing in some cases reduction in root hydraulic conductance (Lehto and Zwiazek 2011). Water relations as well as other properties of AM, EM and NM plants remain to be studied under stress conditions.

The changes in traits in a direction of increased resource use efficiency in AM compared to EM and NM plants, namely larger root branching, SRL and SLA, appear to be in contrast to the smaller biomass in AM plants. In this experiment, the growth of AM plants was slowest at the early stage, possibly due to initial incompatibility with one of the inoculant fungi or some other early-stage growth inhibition. As the relative difference in biomass between EM and AM plants decreased from the first to the second harvest, it follows that AM plants were growing at a faster rate relative to their size. This is in agreement with the indices of efficiency (root branching, SRL, SLA). If the faster growth rate of young alder seedlings with AM applies also to field conditions, it would be an advantage for seedling recruitment. This could be a key to the initial dominance of AM in grey alder, which was shown by Arveby and Granhall (1998) in field conditions in Sweden.

The morphological root traits of AM plants could be interpreted as leading to a highly efficient root system.
The concentrations of several nutrients were indeed highest in the AM plants: $\mathrm{Ca}, \mathrm{K}, \mathrm{Mg}, \mathrm{Mn}, \mathrm{N}, \mathrm{P}$ and $\mathrm{S}$. However, the higher nutrient concentrations in $\mathrm{AM}$ plants can alternatively be a result of their smaller size rather than more efficient uptake. This interpretation is supported by the decrease in most nutrient concentrations between harvests. Moreover, the foliar contents of $\mathrm{B}, \mathrm{N}, \mathrm{Mg}, \mathrm{Mn}$ and $\mathrm{S}$ per plant were lowest in the AM treatment. Phosphorus and $\mathrm{K}$ were exceptions, as their concentrations were clearly higher in AM plants and the contents were similar between treatments. While the changes in morphological traits in the AM root systems suggest improved uptake efficiency, the contribution of the increases in root surface area and density to nutrient uptake depends on the nutrient considered and its availability. In this study the AM plants were able to accumulate as much $\mathrm{P}$ and $\mathrm{K}$ in the foliage as the larger $\mathrm{EM}$ and NM plants, which suggests relatively more efficient uptake of these nutrients by AM. None of the nutrient concentrations were near deficiency despite the treatment differences in these non-stress conditions, although $\mathrm{Cu}$ and $\mathrm{Zn}$ were rather low (on the basis of recommendations for birch, Reinikainen et al. 1998). Boron, $\mathrm{Ca}$ and $\mathrm{Mn}$ showed a different pattern from other nutrients, as their concentrations increased between harvests. As B and Ca have roles in the formation of cell walls (Brown et al. 2002, White and Broadley 2003), their increase suggests an increased requirement and uptake during the development and exponential growth of the seedlings.

The results from earlier studies have been contextdependent. AM formation increased the growth of Salix repens compared to $\mathrm{NM}$, especially at times with low $\mathrm{P}$ in cuttings, even though the AM colonisation was very low, less than 5\% (van der Heijden 2001). In another study, EM increased the aboveground growth of S. repens more than AM compared to non-mycorrhizal status (van der Heijden and Kuyper 2001). In low-P conditions both EM and AM eucalypts grew better than NM (Chen et al. 2000), and Jones et al. (1998) found more $\mathrm{P}$ taken up by EM eucalypts than AM ones. Between-species differences and the form of $\mathrm{P}$ in the substrate are possible explanations for the different results. In our study, soluble $\mathrm{P}$ was available while Jones et al. (1998) grew the plants in a soil-sand mix apparently including organic and complex P forms. In our experiment, all nutrients were in mineral forms in the nutrient solutions including both ammonium and nitrate, and the alder seedlings were able to maintain 
sufficient foliar-N levels in all treatments despite the lack of nitrogen-fixing symbiosis with Frankia.

Tannin concentrations were not significantly different in the different treatments. More work is needed to clarify the changes in plant phenolic accumulation and composition in response to mycorrhizal fungi. Tannins comprise a large investment in terms of carbon, and they are active defence compounds; phenolic compounds may also have a role in limiting the extent of the Hartig net (Feugey et al. 1999). Further studies will show if the difference between mycorrhizal types is larger in stress conditions.

In conclusion, we have shown that grey alder (Alnus incana) can be successfully inoculated with both EMF and AMF under the same growing conditions. The plants in the different treatments differed mainly by the smaller size of AM plants and their higher number of root tips per root length, SRL and SLA and relatively more efficient $\mathrm{P}, \mathrm{K}$ and $\mathrm{Zn}$ accumulation. Photosynthesis per unit leaf area and water relations in non-stressed conditions did not show significant difference, but the higher SLA led to somewhat higher photosynthetic rate per unit mass in AM plants. Fungal species and genotypes are likely to differ from each other, and therefore several isolates should be used in further studies. Grey alder can be used as a model plant for assessing the behaviour of AM and EM symbioses at different levels of organisation, for example in genomics studies and ecophysiological studies on the carbohydrate economy and nutrient uptake in different soil conditions and under environmental stress.

Acknowledgements We thank Dr. Sari Timonen for suggesting Alnus incana as an experimental species, Prof. Riitta JulkunenTiitto for making the Populus tremula clones available, Dr. Mauritz Vestberg for providing the AM inoculants, Lic.Phil. Kauko Salo for identifying Lactarius aspideus sporocarps and Dr. Thorunn Helgason for identifying the alder symbiont as an ascomycete. Jiajun Ye contributed in the Populus screening. Thanks go to laboratory professionals Leena Kuusisto, Maini Mononen and Jaana Vaaranta.

Funding Information The study was funded by the Academy of Finland (grant number 268279). Open access funding provided by University of Eastern Finland (UEF) including Kuopio University Hospital.

Open Access This article is distributed under the terms of the Creative Commons Attribution 4.0 International License (http:// creativecommons.org/licenses/by/4.0/), which permits unrestricted use, distribution, and reproduction in any medium, provided you give appropriate credit to the original author(s) and the source, provide a link to the Creative Commons license, and indicate if changes were made.

Publisher's Note Springer Nature remains neutral with regard to jurisdictional claims in published maps and institutional affiliations.

\section{References}

Adamczyk B, Kitunen V, Smolander A (2008) Protein precipitation by tannins in soil organic horizon and vegetation in relation to tree species. Biol Fert Soils 45:55-64. https://doi. org/10.1007/s00374-008-0308-0

Adamczyk B, Salminen J, Smolander A, Kitunen V (2012) Precipitation of proteins by tannins: effects of concentration, protein/tannin ratio and $\mathrm{pH}$. Int J Food Sci Technol 47:875878. https://doi.org/10.1111/j.1365-2621.2011.02911.x

Adamczyk B, Simon J, Kitunen V, Adamczyk S, Smolander A (2017) Tannins and their complex interaction with different organic nitrogen compounds and enzymes: old paradigms versus recent advances. ChemistryOpen 6:610-614. https://doi.org/10.1002/open.201700113

Arveby AS, Granhall U (1998) Occurrence and succession of mycorrhizas in Alnus incana. Swed J Agr Res 28:117-127 http://agris.fao.org/agris-search/search.do?recordID= SE1999030033

Augé RM, Toler HD, Saxton AM (2015) Arbuscular mycorrhizal symbiosis alters stomatal conductance of host plants more under drought than under amply watered conditions: a metaanalysis. Mycorrhiza 25:13-24. https://doi.org/10.1007 /s00572-014-0585-4

Brown PH, Bellaloui N, Wimmer MA, Bassil ES, Ruiz J, Hu H, Pfeffer H, Dannel F, Römheld V (2002) Boron in plant biology. Plant Biol 4:205-223. https://doi.org/10.1055/s2002-25740

Chen Y, Brundrett M, Dell B (2000) Effects of ectomycorrhizas and vesicular-arbuscular mycorrhizas, alone or in competition, on root colonization and growth of Eucalyptus globulus and E. urophylla. New Phytol 146:545-556. https://doi. org/10.1046/j.1469-8137.2000.00663.x

Chen W, Koide RT, Adams TS, DeForest JL, Cheng L, Eissenstat DM (2016) Root morphology and mycorrhizal symbioses together shape nutrient foraging strategies of temperate trees. P Natl Acad Sci USA 113:8741-8746. https://doi. org/10.1073/pnas.1601006113

Corrêa A, Gurevitch J, Martins-Loução MA, Cruz C (2012) C allocation to the fungus is not a cost to the plant in ectomycorrhizae. Oikos 121:449-463. https://doi. org/10.1111/j.1600-0706.2011.19406.x

Daughtridge A, Boese S, Pallardy S, Garrett H (1986) A rapid staining technique for assessment of ectomycorrhizal infection of oak roots. Can J Bot 64:1101-1103

van der Heijden EW (2001) Differential benefits of arbuscular mycorrhizal and ectomycorrhizal infection of Salix repens. Mycorrhiza 10:185-193 
van der Heijden EW, Kuyper TW (2001) Laboratory experiments imply the conditionality of mycorrhizal benefits for Salix repens: role of $\mathrm{pH}$ and nitrogen to phosphorus ratios. Plant Soil 228:275-290. https://doi.org/10.1023 /A:1004850423794

van der Heijden E, Vosatka M (1999) Mycorrhizal associations of Salix repens L. communities in succession of dune ecosystems. II. Mycorrhizal dynamics and interactions of ectomycorrhizal and arbuscular mycorrhizal fungi. Can J Bot 77:1833-1841. https://doi.org/10.1139/b99-173

Egerton-Warburton L, Allen M (2001) Endo- and ectomycorrhizas in Quercus agrifolia nee. (Fagaceae): patterns of root colonization and effects on seedling growth. Mycorrhiza 11:283290. https://doi.org/10.1007/s005720100134

Feugey L, Strullu D, Poupard P, Simoneau P (1999) Induced defence responses limit Hartig net formation in ectomycorrhizal birch roots. New Phytol 144:541-547. https://doi.org/10.1046/j.1469-8137.1999.00538.x

Gehring CA, Mueller RC, Whitham TG (2006) Environmental and genetic effects on the formation of ectomycorrhizal and arbuscular mycorrhizal associations in cottonwoods. Oecologia 149:158-164. https://doi.org/10.1007/s00442006-0437-9

Giovannetti M, Mosse B (1980) Evaluation of techniques for measuring vesicular arbuscular mycorrhizal infection in roots. New Phytol 84:489-500. https://doi.org/10.1111 /j.1469-8137.1980.tb04556.x

Grace C, Stribley DP (1991) A safer procedure for routine staining of vesicular-arbuscular mycorrhizal fungi. Mycol Res 95:11601162. https://doi.org/10.1016/S0953-7562(09)80005-1

Hagerman A, Butler L (1978) Protein precipitation method for the quantitative determination of tannins. J Agric Food Chem 26: 809-812. https://doi.org/10.1021/jf60218a027

Halonen O, Tulkki H, Derome J (1983) Nutrient analysis methods. Finnish Forest Research Institute Research Papers 121:1-28 http://jukuri.luke.fi/handle/10024/520681

Harley JL, Harley EL (1987) A check-list of mycorrhiza in the British flora. New Phytol 105:1-102. https://doi.org/10.1111 /j.1469-8137.1987.tb00674.x

Johnson NC, Wilson GWT, Bowker MA, Wilson JA, Miller RM (2010) Resource limitation is a driver of local adaptation in mycorrhizal symbioses. Proc Natl Acad Sci U S A 107: 2093-2098. https://doi.org/10.1073/pnas.0906710107

Jones MD, Durall DM, Tinker PB (1998) Comparison of arbuscular and ectomycorrhizal Eucalyptus coccifera: growth response, phosphorus uptake efficiency and external hyphal production. New Phytol 140:125-134. https://doi. org/10.1046/j.1469-8137.1998.00253.x

Kilpeläinen J, Vestberg M, Repo T, Lehto T (2016) Arbuscular and ectomycorrhizal root colonisation and plant nutrition in soils exposed to freezing temperatures. Soil Biol Biochem 99:8593. https://doi.org/10.1016/j.soilbio.2016.04.025

Kilpeläinen J, Barbero-López A, Vestberg M, Heiskanen J, Lehto T (2017) Does severe soil drought have after-effects on arbuscular and ectomycorrhizal root colonisation and plant nutrition? Plant Soil 418:377-386. https://doi.org/10.1007 /s11104-017-3308-8

Korhonen A, Lehto T, Heinonen J, Repo T (2019) Whole-plant frost hardiness of mycorrhizal (Hebeloma sp. or Suillus luteus) and non-mycorrhizal scots pine seedlings. Tree Physiol. In press. https://doi.org/10.1093/treephys/tpy105
Kramer PJ, Boyer JS (1995) Water relations of plants and soils. Academic press, San Diego. ISBN 0-12-425006-0 2

Lehto T (1992) Effect of drought on Picea sitchensis seedlings inoculated with mycorrhizal fungi. Scand J For Res 7:177182

Lehto T, Zwiazek JJ (2011) Ectomycorrhizas and water relations of trees: a review. Mycorrhiza 21:71-90. https://doi. org/10.1080/02827589209382710

Liese R, Alings K, Meier IC (2017) Root branching is a leading root trait of the plant economics spectrum in temperate trees. Front Plant Sci 8:315. https://doi.org/10.3389 /fpls.2017.00315

Lodge DJ (1989) The influence of soil-moisture and flooding on formation of VA-endo- and ectomycorrhizae in Populus and Salix. Plant Soil 117:243-253. https://doi.org/10.1007 /BF02220718

Luginbuehl LH, Menard GN, Kurup S, Van Erp H, Radhakrishnan GV, Breakspear A, Oldroyd GED, Eastmond PJ (2017) Fatty acids in arbuscular mycorrhizal fungi are synthesized by the host plant. Science 356:1175-1178. https://doi.org/10.1126 /science.aan0081

Markwell J, Osterman JC, Mitchell JL (1995) Calibration of the Minolta SPAD-502 leaf chlorophyll meter. Photosynth Res 46:467-472. https://doi.org/10.1007/BF00032301

Moora M (2014) Mycorrhizal traits and plant communities: perspectives for integration. J Veg Sci 25:1126-1132. https://doi. org/10.1111/jvs.12177

Murashige T, Skoog F (1962) A revised medium for rapid growth and bio assays with tobacco tissue cultures. Physiol Plantarum 15:473-497. https://doi.org/10.1111/j.13993054.1962.tb08052.x

Ostonen I, Püttsepp U, Biel C, Alberton O, Bakker MR, Lõhmus K, Majdi H, Metcalfe D, Olsthoorn AFM, Pronk A, Vanguelova E, Weih M, Brunner I (2007) Specific root length as an indicator of environmental change. Plant Biosyst 141: 426-442. https://doi.org/10.1080/11263500701626069

Plassard C, Bonafos B, Touraine B (2000) Differential effects of mineral and organic $\mathrm{N}$ sources, and of ectomycorrhizal infection by Hebeloma cylindrosporum, on growth and $\mathrm{N}$ utilization in Pinus pinaster. Plant Cell Environ 23:11951205. https://doi.org/10.1046/j.1365-3040.2000.00630.x

Possen BJHM, Anttonen MJ, Oksanen E, Rousi M, Heinonen J, Kostiainen K, Kontunen-Soppela S, Heiskanen J, Vapaavuori EM (2014) Variation in 13 leaf morphological and physiological traits within a silver birch (Betula pendula) stand and their relation to growth. Can J For Res 44:657-665. https://doi.org/10.1139/cjfr-2013-0493

Querejeta JI, Egerton-Warburton LM, Allen MF (2009) Topographic position modulates the mycorrhizal response of oak trees to interannual rainfall variability. Ecology 90: 649-662. https://doi.org/10.1890/07-1696.1

Randriamanana T, Wang F, Lehto T, Aphalo PJ (2012) Water use strategies of seedlings of three Malagasy Adansonia species under drought. S Afr J Bot 81:61-70. https://doi.org/10.1016 /j.sajb.2012.05.005

Randriamanana TR, Nybakken L, Lavola A, Aphalo PJ, Nissinen K, Julkunen-Tiitto R (2014) Sex-related differences in growth and carbon allocation to defence in Populus tremula as explained by current plant defence theories. Tree Physiol 34:471-487. https://doi.org/10.1093/treephys/tpu034 
Reinikainen A, Veijalainen H, Nousiainen H (1998) Puiden ravinnepuutokset - metsänkasvattajan ravinneopas. Finnish Forest Research Institute Research Papers 688:1-44 http://jukuri.luke.fi/handle/10024/521320

Riddoch I, Lehto T, Grace J (1991) Photosynthesis of tropical tree seedlings in relation to light and nutrient supply. New Phytol 119:137-147. https://doi.org/10.1111/j.1469-8137.1991. tb01017.x

Saravesi K, Markkola A, Rautio P, Tuomi J (2011) Simulated mammal browsing and host gender effects on dual mycorrhizal Salix repens. Botany 89:35-42. https://doi.org/10.1139 /B10-081

Soudzilovskaia NA, Douma JC, Akhmetzhanova AA, van Bodegome PM, Cornwell WK, Moens EJ, Treseder KK, Tibbett M, Wang YP, Cornelissen JH (2015) Global patterns of plant root colonization intensity by mycorrhizal fungi explained by climate and soil chemistry. Global Ecol Biogr 24:371-382. https://doi.org/10.1111/geb.12272

Thormann MN, Currah RS, Bayley SE (1999) The mycorrhizal status of the dominant vegetation along a peatland gradient in southern boreal Alberta, Canada. Wetlands 19:438-450. https://doi.org/10.1007/BF03161775
U.S. EPA (2007). Method 3051A (SW-846): microwave assisted acid digestion of sediments, sludges, soils and oils, revision 1 . Was hington, D C. ht t p s:// w w w. e pa. gov/sites/production/files/2015-12/documents/3051a.pdf

Vargas R, Baldocchi DD, Querejeta JI, Curtis PS, Hasselquist NJ, Janssens IA, Allen MF, Montagnani L (2010) Ecosystem $\mathrm{CO}_{2}$ fluxes of arbuscular and ectomycorrhizal dominated vegetation types are differentially influenced by precipitation and temperature. New Phytol 185:226-236. https://doi. org/10.1111/j.1469-8137.2009.03040.x

Wang F (2017) SIOX plugin in ImageJ: area measurement made easy. UV4Plants Bulletin 2016(2):37-44. https://doi. org/10.19232/uv4pb.2016.2.11

White PJ, Broadley MR (2003) Calcium in plants. Ann BotLondon 92:487-511. https://doi.org/10.1093/aob/mcg164

Withington JM, Reich PB, Oleksyn J, Eissenstat DM (2006) Comparisons of structure and life span in roots and leaves among temperate trees. Ecol Monogr 76:381-397. https:// doi.org/10.1890/0012-9615(2006)076[0381: COSALS]2.0.CO;2 